Dr Atkinson said, however, that joint projects would be given more active encouragement than in the past, including a major publicity campaign aimed at both industry and universities. Industry was less willing than in the past to risk money on basic research and long-term goals, and was increasingly focusing on product improvement. "Given these trends, the nation is becoming more dependent than ever on universities and colleges to provide the basic research for new technologies and products," he said.

Last week's move follows past criticism from Congress that industry has not been able to compete for research funds on the same basis as university research scientists, a point heavily stressed, for example, by Senator Edward Kennedy during last year's authorisation hearings.

One outcome has been a recent decision by the National Science Board to amend its language covering applications from industry for such grants. Previously it had stated that these would only be considered under certain circumstances, namely if the research was of national importance, or if industry was able to provide unusual expertise or instrumental capability. The new wording is more positive, indicating merely the type of applications that will not-rather than will--be considered.

A particular point stressed by NSF officials is that the delay before pay-off from basic research is a deterrent to industry investing in this area, and that NSF funding might help redress the situation, for example, allowing those scientists who have joined industry because of a lack of jobs in more academic settings to carry out basic science projects.

This argument is not likely to carry much weight with industry, which has recently been telling the government that basic research is a federal responsibility, while development activities should be left to the private sector (a message reflected in the proposed shape of $R \& D$ funding within the President's 1979 budget request to Congress).

The sector which is likely to respond much more to the NSF's rallying cry are the small, knowledge-intensive, high-technology firms-such as those distributed around Boston's famous Route 128-many of whom have been experiencing financial difficulties in recent years.

Such firms, however, are rarely interested in basic research as such, even in the long-term. Their main concern-for which there is at present a lack of money-is finding ways of turning a good idea into a marketable product. And this is where, in practice, NSF support will be in greatest demand.

David Dickson

\title{
Argentina: US National Academy of Sciences to send delegation
}

THE Human Rights Committee of the US National Academy of Sciences is to send a small delegation to Argentina next month to investigate charges of repression against scientists.

The delegation, which will also visit Uruguay, will consist of Dr Christian Anfinsen of the National Institution of Arthritis, Metabolic and Digestive Diseases, Nobel Prize Winner in 1972 for work on the structure of proteins, Dr Robert Perry, of the Institute of Cancer Research in Philadelphia, and a member of the NAS staff.

During a ten-day visit to Buenos Aires and Montevideo, the delegation will talk with both scientists and government officials about scientific co-operation with the US, and about the situation of scientists in the two South American countries.

The NAS delegation's visit follows a recent trip to Argentina by $\mathrm{Mr}$ Emilio Daddario, president of the American Association for the Advancement of Science, and until recently director of the Office of Technology Assessment. $\mathrm{Mr}$ Daddario said in Washington last week that the actions of the security forces in Argentina had, with a few exceptions, "made a shambles" of scientific freedom, and that reports reaching the West of repression against individual scientists were not exaggerated.
Referring to moves by western scientists to boycott the International Union Against Cancer congress, due to take place in Buenos Aires in October, $\mathrm{Mr}$ Daddario said that many of the scientists he had spoken to in Argentina felt it important to maintain contact with their colleagues in other countries, particularly since many of them lacked funds to travel to conferences and meetings abroad.

However he also said that government officials had asked him about the attitude of foreign scientists to the cancer congress, and that he had the impression that they were concerned to appear to maintain normal international relations with the scientific community.

Meanwhile moves are gaining momentum in the US to boycott the congress in protest at the treatment of scientists in Argentina since the army came to power in March 1976. Since that date, many scientists have been reported to have been arrested or abducted without formal charges.

Last month at a meeting of American Cancer Society Research professors in Phoenix, Arizona, all 39 present found that they were unanimous in their individual decisions not to attend the congress if it is held in Argentina as planned.

David Dickson

\section{France falls out with Pakistan over reprocessing}

PAKISTAN's reaction to the latest move of the French government to modify the accord of 1976 on building a nuclear reprocessing plant, has been quite firm and unequivocal. In view of strong public statements there appears little chance that the Pakistani government will succumb to any retraction from the agreement, or soft-pedalling. A Foreign Office spokesman in Islamabad said that the government would not accept any change or modification in the agreement already reached.

The French want to substitute a coprocessing plant for the planned plutonium reprocessing plant to guard against separation of plutonium that could be used in explosive devices. A co-processing plant can only reprocess the spent fuel once or twice for use in reactors and it does not produce plutonium. Pakistan's nuclear thinktank, however, has plans for using plutonium, particularly when it develops its fast breeder programme.

Mr Munir Ahmad Khan, the Chairman of PAEC (the Pakistan Atomic
Energy Commission), when asked for the rationale behind the timing of the setting up of the reprocessing plant, explained that PAEC wanted to synchronise the installation of the reprocessing plant with the commissioning of a few more reactors, but that for various reasons the reactor programme is running behind schedule. Mr Munir Ahmad explained, however, that the reprocessing technology is highly sophisticated and takes longer to set up than a reactor.

His team would like enough time to acquire the necessary experience in reprocessing technology for its optimum use. Hence, the hurry for the reprocessing plant.

At Chashma, the site of the proposed plant (plus a $600 \mathrm{MW}$ reactor), the foundation concreting is in progress in anticipation of things ultimately working out as planned.

In his recent address to the Institute of International Affairs in Karachi, $\mathrm{Mr}$ Munir Ahmad explained the technical and economic reasons for building a 
reprocessing plant in a country like Pakistan-which is planning on deriving almost half its energy supply from nuclear sources by the end of the century. Even the $2,000 \mathrm{MW}$ from the big earth-filled Tarbela dam, he claimed, would be insignificant in filling the country's energy gap. And oil-fired power stations were becoming less viable, especially as Pakistan had so far struck almost no ail or good quality coal. So, the only option, according to Mr Munir Ahmad, would be the nuclear one.

His view is that in the overall nuclear fuel economy framework, reprocessing of used fuel plus plutonium is inescapable. Jacques Couture, sales manager of the reprocessing division of the French company, Compagnie Generale des Matiere Nuclearies, has not missed his opportunity to blow the re- processing trumpet. He has said that "with a typical light-water reactor which needs about 180 tonnes of natural uranium a year, the annual saving will be at least 40 tonnes, or even 70 tonnes if the plutonium recovered during reprocessing as well as the uranium is recycled." In fast breeder reactors, the fuel is some $20 \%$ plutonium oxide in uranium oxide, and the nuclear expert's view here is that a co-processing plant that cannot deliver plutonium is, therefore, not of much value, seen in that context.

Mr Munir Ahmad was vehement in his address on the topic of proliferation. He said that the safeguard imposed by IAEA had been fully incorporated in the agreement and that the French had imposed some additional safeguards. He saw no valid reason for the scepticism which had been shown, and thought it might not be unfair to conclude that the motive for changing the agreement was to deny a developing country a useful, sophisticated technology of future.

Pakistan has sizable deposits of uranium and thorium-bearing minerals. Pakistani scientists are exploring the possibility of exploiting the indigenous sources of thorium in a thoriumuranium-233 cycle in fast breeder reactors, for which plutonium is essential.

The French have developed a proliferation-free uranium enrichment process--a chemical exchange methodbut it is unlikely to be commercially viable for another decade or so. Likewise, the French concept of the coprocessing plant has yet to be commercially accepted as it has not been tried in any other country.

Axim Kidwai

\section{Europe's nuclear circus}

Plenty of shadow-boxing went on at last week's open discussions on nuclear energy organised by the European Commission, with no side quite hitting home but nevertheless a lot of energy expended. The proceedings were launched by news of an accident at one of Belgium's nuclear plants on 13 January. The accident was made public by the Environmental Protection Society who claimed that 80 people were contaminated by radium-131 and that the affair had been covered up by government authorities.

The news caused quite a scare in Belgium, but was ridiculed by speakers at the nuclear debate, doctors, and the director of the Tihange plant near Liège, where the leak occurred.

The so-called 'father of the $\mathrm{H}$ bomb', Dr Edward Teller, a leading US nuclear physicist at the Hoover Institute for War, Revolution, and Peace, Stanford, California, told the nuclear hearings panel and an audience of several hundred that he was 'more alarmed' at the kidnapping of Baron Edouard Empain in Paris by terrorists, than by the Belgian leak. The Hungarian-born scientist claimed that he had been exposed to more radiation when he flew over Europe to be present at the hearings.

The state-run electricity company, responsible for the Tihange plant, put the figure of people involved at between 30 and 60 . Director Robert Van den Damme said that no members of the public were involved during the accident which happened during an annual maintenance check. $\mathrm{He}$ said that workers ignored the leak until the job was done. Six people had to be examined by doctors, who they said had been contaminated by 100 millirems of radium-131. They added that the maximum tolerated dose was 3,000 millirems for 13 weeks before the possibility of thyroid cancer occurred.

The Friends of the Earth argued that the principal issue was one of disclosure; that the authorities should have made the accident public and that their natural reaction had been to conceal it. But $\mathrm{Mr}$ Van den Damme denied that the affair had been hushed up. He said that the leak had not escaped from the plant and had therefore done no damage to the environment or the surrounding population. "It was not worthwhile to publish information about something that did not happen".

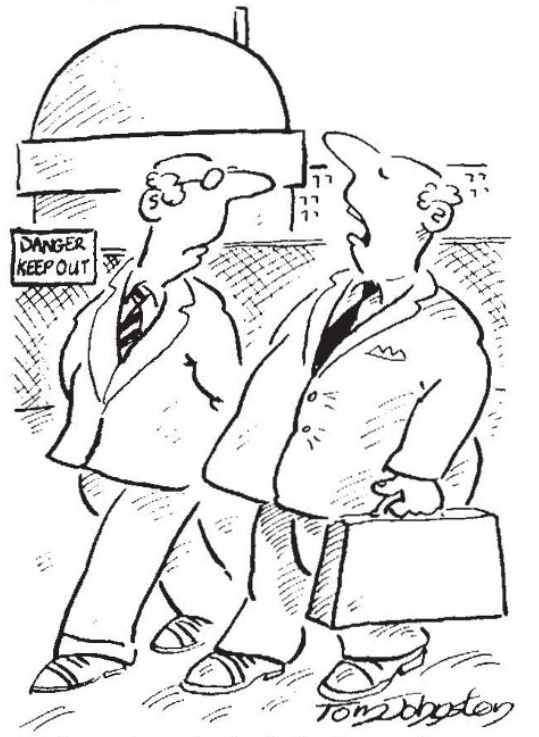

"If there is a leak, let's hope there are some terrorists in the area!"
The news did manage to give the Commission's nuclear hearings more relevance. The session ended after three days of heated debate between the supporters of nuclear energy and its critics. The highlight for many was described as a "confrontation" between two old debating partners, Robert Jungk, an Austrian futurologist opposed to the use of nuclear energy. and the controversial Dr Teller.

The theme of the session 'Economic growth and energy options: implications for safety, health and environmental protection', considered the problems of terrorist activities and the proliferation of nuclear weapons. Jungk argued that increased security measures to guard against the two problems could lead to centralisation and therefore police states. He said that this was a form of mental pollution that was not acceptable and advocated the immediate suspension of the nuclear energy programme.

Dr Teller hit back by describing what he termed as the worst possible pollution, that of poverty. He argued that the developed countries should devote their energy to developing nuclear power. He said that oil should be given to the third world to enable it to develop, whereas nuclear power was economically and structurally beyond its reach. And he put paid to terrorists by theatrically declaring that "the only way to get rid of terrorism is to get rid of terrorists".

The debate at least guaranteed a full house. EEC energy commissioner Guido Brunner made no final assessment of the findings of the hearings. Critics claim that there was never an intention of altering the Commission's approach to energy policy as a result of the debate.
Patricia Kelly 